\title{
Ecological Balance in the Metaphor of the Novel- Partikel by Dewi Lestari (Eco-linguistic Study)
}

\author{
Risti Luluk Nur Afidah ${ }^{1}$, Suyitno ${ }^{2}$, Raheni Suhita $^{3}$
}

Postgraduate Program of Indonesian Language Education, Sebelas Maret University, Surakarta, Indonesia

Received: 22 Nov 2021; Received in revised form: 31 Dec 2021; Accepted: 07 Jan 2022; Available online: 16 Jan 2022 (C)2022 The Author(s). Published by Infogain Publication. This is an open access article under the CC BY license (https://creativecommons.org/licenses/by/4.0/).

\begin{abstract}
Ecology and environment by Haugen are used as analogies in creating the metaphor of ecology. Languages that exist in the world have various forms that lead to the emergence of interactions between languages. And the use of the ecological metaphor that appears from the study of ecolinguistics is to explain the relation between these languages. This study aims to reveal and describe the types of ecological metaphors in the novel Partikelby Dewi Lestari. The data source in this research is the novel Partikel by Dewi Lestari. The research procedure used to analyze the aspect of the metaphor uses a qualitative descriptive method. The data analysis technique used is the flow analysis model. Based on the results of data analysis on the novel Partikel by Dewi Lestari, four types of ecological metaphors were found, namely 1) anthropomorphic metaphors; 2) animal metaphors; 3) abstraction metaphor; and 4) metaphorical synaesthesia.
\end{abstract}

Keywords-Ecology, metaphor, language, balance.

\section{INTRODUCTION}

Along with the increasing number of people on earth, the needs of life will also increase. This is one of the causes of the environment being sacrificed in order to meet the needs of life. Such as mining to produce oil, coal, diamonds, and gold which causes forests to be destroyed due to excavations.Forest burning to clear land for oil palm plantations which causes flooding. And the disposal of factory waste into the river which causes environmental pollution.

Exploitation on a large scale that is carried out without thinking about the long-term impact will be harmful to the environment. The damaged natural environment can affect living things. This is due to the imbalance of the ecosystem, so that living things cannot meet the needs of life which results in disturbances in preserving offspring. Therefore, it is important that there is awareness from the community to protect the environment.

Ecological balance can be seen from the quality of the environment, normal functioning and all components involved in the response to action. The quality of the envi- ronment can be seen from the actions and reactions carried out by each part. The components that make up an ecosystem not only exist, but must have a function. When a part exists and functions by itself, it creates an ecological balance. Make sure each part is not lost Its function is the ability to bring balance.

As part of nature, it is our obligation to keep the balance of nature for the survival of all creatures. Based on Law no. 32 of 2009, environmental protection and management is a systematic and integrated effort to preserve environmental functions. Caring for the environment can start from something simple, such as using water wisely, disposing of garbage in the provided place, reducing the use of plastic, and using electricity wisely.

According to William Chang in (Susilo., 2010) the continuity of the interwoven relation between humans and nature is in line with the background of the historical formation of human and natural relations followed by all forms of life patterns. The natural environment related to human life is a form of ecology. Humans in setting up relation during society need a tool to communicate, the 
tool is called language.

According to Haugen, the relation between language and the environment can be studied using eco-linguistic studies. Eco-linguistics according to Mbete(Kurniasari, 2019) not only examines the relation between language and the environment, but also humans with language and the reciprocal relation between humans and the natural environment.Then, by Haugen the relation of language and environment is used as an analogy in creating an ecological metaphor. The existence of various forms of language in the world causes the emergence of interactions between languages. Therefore, the use of ecological metaphors is to explain these relations.

Haugen tries to explain the form of metaphor that exists in society, both language in the natural, social, and cultural environment. Metaphors are closely related to the role of the structure of human speech, including as a tool for channelling emotions, expressing oneself, as a source of polysemy and synonyms, and conveying motivation.(Ullman, 2007)divides metaphors into four types, namely 1) anthropomorphic metaphors; 2) animal metaphors; 3) abstraction metaphor; and 4) metaphorical synaesthesia.

The relation between language and the environment is a complex matter, so it becomes the focus of interesting research. As done by (Steffensen, 2014)trying to do a search on the emergence and development of ecological linguistics or what is called eco-linguistics. After that compare ecology with the form-based traditions of 20th century linguistics.

Language as a communication tool is always used by humans to interact. Then, language is expressed in the form of a novel as a form of communication by the author. Novel is a communication tool used by the author to the reader. (Nurgiyantoro, 2010)argues that the novel is a work of fiction that presents a world of imaginative and ideal life. Novels can be a medium for standing for views, ideas, and the world of images that have the potential to express and describe the environment. As a world of images, novels have interpreted phenomena that occur in society related to environmental issues.

One of them is the work of Dewi Lestari, namely the novel Partikel. The novel is a work of science fiction. The selection of the novel Partikelby Dewi Lestari as research material because the story discusses a lot about nature, the environment, and life around us, and there are many moral messages that are extremely useful for readers.
This research uses a qualitative descriptive method with content analysis techniques, namely an approach that focuses on the study of content analysis in a literary work. The literary work in question is the novel Partikel by Dewi Lestari. The focus of this research is the type of ecological metaphor in the novel Partikel. The data collection technique used is a content analysis technique of literary works in the form of novels. This data collection was carried out through three stages as revealed by (Cresswell, 2014)which consisted of: (1) reading the data source; (2) data retrieval by placing a marker on the text; and (3) recording of relevant texts. Data analysis was carried out interactively based on the concept of (Huberman, 1994)namely a flow analysis model consisting of: 1) data collection, 2) reduction, 3) data presentation, and 4) data verification.

\section{RESULTS AND DISCUSSION}

In this section, the results of the research on the novel Partikel by Dewi Lestari related to the types of ecological metaphors will be presented which include: (1) anthropomorphic metaphors referring to inanimate objects compared to the transfer of human body, senses, or feelings; (2) animal metaphors use animals, animal body parts, or something related to animals to describe an image of something else; (3) abstraction metaphor is the expression of concrete things to be abstract; and (4) this synaesthesia metaphor is a type of metaphor that is based on the transfer of the senses (Ullman, 2007). In the following, a discussion about the types of ecological metaphors in the novel Partikel by Dewi Lestari will be presented.

\section{Anthropomorphic Metaphor}

1) Fred Dunston, my friend from Wildlife Conservation Society, convinced me many times that Madididwarfed the collection of flora and fauna of Manu National Park, the prima donna of the Amazon, to become like the Bogor Safari Park (Lestari, 2021: 5).

In the quote above, which includes anthropomorphic metaphors, Madidi dwarfs the collection of flora and fauna.Mengkerdilkan(dwarfing) comes from the word kerdil (dwarfism) is a short stature caused by a genetic or medical condition that affects a person's bone growth. From the excerpt, there is a transfer from human disease to an act that Madidi can change flora and fauna into small ones. The excerpt implies that Madidi has a rich collection of flora and fauna species, so that what is in it looks small and cramped.

\section{RESEARCH METHOD}


2) 2) In the hull of tropical forests, it is common for humans to shrink into fleas who get lost in the contortions of sheep's fur(Lestari, 2021).

In the excerpt above, the anthropomorphic metaphor is the hull of a tropical forest. The stomach is an organ found in the upper left part of the abdomen that functions as a digestive organ. The use of the word stomach is used to compare the depths of a dense, dark, and humid forest as in the human stomach. The meaning contained in the excerpt is that if humans are in a tropical forest, they will appear exceedingly small because there are still many larger animals.

3) My body that is 172 centimetres tall is like a bonsai when I am next to it (Lestari, 2021: 7).

The excerpt above which includes anthropomorphic metaphors is that my body is 172 centimetres tall like a bonsai. Bonsai is a plant that is deliberately reduced in a pot as an ornamental plant. In the excerpt there is a transfer of a person's height into the plant. The meaning contained is that everyone will look tall if they are close to someone who is the right height.

\section{Animal Metaphor}

4) In the hull of tropical forests, often the status of humans shrinks into fleas who get lost in the contortions of sheep's fur (Lestari, 2021: 6).

In the excerpt above, which shows the animal metaphor is that humans have shrunk to fleas. Fleas are small animals that become parasites on other animals. From the excerpt, there is a transfer from humans to animals called fleas. Humans living in tropical forests are likened to tiny fleas on the bodies of other animals covered with thick and dark fur. Tropical forests have tall trees that cover the forest floor, this makes the forest look dark and feel moist.

5) Carolus Linnaeus coined the term hominidae for humans and separated chimpanzees from the word pongidae because he was afraid of being scolded by the church. So, we are animals, Zarah. Animals that have high linguistic abilities because they have Broca's Area (Lestari, 2021: 19).

In the excerpt above which signifies the animal metaphor is "So, we are animals, Zarah." Animals with linguistic abilities. The shift that occurs in the excerpt above is from humans to animals. It means that humans are like animals, the only difference being that they can speak.

6) According to my father, fungi are the ancestors of the human species. Both breathe oxygen and exhale carbon dioxide, both have high intelligence, both are network creatures. Because of this close resemblance, fungi and humans have a unique relation.According to my father, fungi are the ancestors of the human species. Both breathe oxygen and exhale carbon dioxide, both have high intelligence, both are network creatures. Because of this close resemblance, fungi and humans have a unique relation (Lestari, 2021: 24).

The quote above which shows the animal metaphor is that fungi are the ancestors of the human species. The word species is used to classify one or more groups of living things. There is a transfer of human groups into animals by using the word species. The meaning in the excerpt above is that as living beings who have a prominent level of intelligence, humans should protect nature as fungi do.

\section{Abstraction Metaphor}

7) According to my father, fungi are nature's parents(Lestari, 2021: 21).

In the excerpt above, which shows the abstraction metaphor is that fungi are the parents of this nature. The abstract form of this expression is found in the word parents.Parents have the meaning of people who have blood relations with children. Fungi as plants which are considered as nature's parents become abstract because actually no one knows for sure what creatures were first on earth.However, the word parents referring to fungi in the excerpt is considered a creature that has prepared life for other living things.

8) Fungi prepare land for plants because they can "chew" on rocks(Lestari, 2021: 21).

In the excerpt above, which shows the abstraction metaphor is that they can "chew" rocks. The abstract form of this expression is found in the word chew. Chewing has the real meaning of crushing food which is usually done by living things such as humans and animals. However, the word chewing in the excerpt is crushing which implicitly shows the phenomenon of turning rocks into soil to form land.

9) Fungi are conscious creatureswhich know and can sense the existence of other beings.

The use of the word conscious creature in the excerpt above is a form of abstraction from plants into human nature. Conscious creatures refer to humans who have reason to think, while fungi are plants that do not have reason and are unable to do anything. The meaning in the excerpt is that as a creature who has reason, it should be able to protect nature and the life around it, because there are not only one group living on earth, but many other groups that must be preserved (Lestari, 2021: 24). 


\section{Synaesthesia Metaphor}

10) I turned to the ground, found it also bumpy and breathing. (Lestari, 2021: 145)

In the excerpt above which shows the metaphor of synaesthesia is I turned my head to the ground, found it also bumpy and breathing.This expression shows an exchange between the sense of sight in the form of turning and the sense of smell in the form of breathing. The meaning of the quote above is that nature also lives like a human who moves and breathes.

11) He told the story of the Sekonyer River, about how it kept swallowing enormous quantities of gold mining waste and how its colour grew cloudier day by day. (Lestari, 2021: 179-180)

The excerpt above which shows the metaphor of synaesthesia is the river continues to swallow gold mine waste in enormous quantities and how the colour is getting cloudier.Swallowing is part of the sense of taste which is then transferred to the sense of sight in the word colour. The quote means that rivers polluted by gold mining waste cause damage to the river ecosystem.

\section{CONCLUSION}

Based on the results of data analysis in the novel Partikel by Dewi Lestari, human life will always be related to nature. Human life will always be juxtaposed with the surrounding natural environment. In the obtained metaphorical data, words, phrases, or sentences are found that are juxtaposed with the characteristics of flora and fauna. This cannot be separated because the environment and nature have a significant role in human life. The results of the research prove that in the novel Partikelby Dewi Lestari, there are four types of ecological metaphors consisting of 1) anthropomorphic metaphor; 2) animal metaphor; 3) abstraction metaphor; and 4) synaesthesia metaphor.

\section{REFERENCES}

[1] Cresswell, J. (2014). Research design: qualitative, quantitativ, and mixed method approach Thousand Oaks, . Thousand Oaks CA: Sage publication in.

[2] Huberman, M. M. (1994). Qualitative Data Analysis. USA: Sage Publication.

[3] Kurniasari, Y. R. (2019). Nilai-Nilai Kearifan Lokal dalam Permainan Tradisioal Cublak-Cubla Suweng di Yogyakarta: Kajian Ekolinguistik. Jurnal Pendidikan Bahasa dan Sastra Indonesia, 8(2), 134-142.

[4] Lestari, D. (2021). Partikel. Yogyakarta: Bentang Pustaka.

[5] Nurgiyantoro, B. (2010). Teori Pengkajian Fiksi. Yogyakarta: UGM Press.

[6] Steffensen, S. a. (2014). Sosiologi Lingkungan. Jakarta: PT Raja Grafindo Press.
[7] Susilo., R. K. (2010). Ecolinguistics: thestate of the art andfuture horizons. Elseiver, 41(Part A), 6-25.

[8] Ullman, S. (2007). Pengantar Semantik. Yogyakarta: Pustaka Pelajar. 